\title{
EARLY SPRING APPLICATION OF AMINOETHOXYVINILGLYCINE (AVG) INCREASES FRUIT SET AND YIELD OF 'ROCHA' PEARS'
}

\author{
MATEUS DA SILVEIRA PASA ${ }^{2}$, BRUNO CARRA ${ }^{3}$, CARINA PEREIRA DA SILVA ${ }^{4}$, \\ MARLISE NARA CIOTTA ${ }^{5}$, ALBERTO FONTANELLA BRIGHENTI ${ }^{2}$, ADÍLSON JOSÉ PEREIRA ${ }^{6}$
}

\begin{abstract}
The low fruit set is one of the main factors leading to poor yield of pear orchards in Brazil. Ethylene is associated with abscission of flowers and fruitlets. Then, the application of ethylene synthesis inhibitors, such as AVG, is a potential tool to increase fruit set of pears. The objective of this study was to evaluate the effect of AVG, sprayed at different rates and timings, on fruit set, yield and fruit quality of 'Rocha' pear. The study was performed in a commercial orchard located in the municipality of São Joaquim, SC, during the growing seasons of 2014/2015 and 2015/2016. Plant material consisted of 'Rocha' pear trees grafted on quince rootstock 'BA29'. AVG was tested at different rates (60 $\mathrm{mg} \mathrm{L}^{-1}$ and $\left.80 \mathrm{mg} \mathrm{L}^{-1}\right)$ and timings [full bloom, one week after full bloom (WAFB), and two WAFB), either alone or in combination. The experiment was arranged in a randomized block design, with at least five single-tree replications. The fruit set, number of fruit per tree, yield, estimated yield, fruit weight, return bloom, and fruit quality attributes were assessed. Fruit set and yield were consistently increased by single applications of AVG at 60 and $80 \mathrm{mg} \mathrm{L}^{-1}$ at both one and two weeks after full bloom, without negatively affecting fruit quality attributes and return bloom. Index terms: Pyrus communis, plant growth regulators, ethylene inhibitor, fruit drop, fruit quality.
\end{abstract}

\section{APLICAÇÃO DE AMINOETOXIVINILGLICINA (AVG) NO INÍCIO DA PRIMAVERA AUMENTA A FRUTIFICAÇÃO EFETIVA E PRODUTIVIDADE DE PEREIRAS 'ROCHA'}

\begin{abstract}
RESUMO - A baixa frutificação efetiva é um dos principais fatores responsáveis pela baixa produtividade dos pomares de pera no Brasil. O etileno está associado com a abscisão de flores e frutos jovens. Logo, a aplicação de inibidores da síntese de etileno, como AVG, apresenta potencial para aumentar a frutificação efetiva de pereiras. Objetivou-se a avaliação do efeito da aplicação de AVG, em diferentes doses e épocas, na frutificação efetiva, na produtividade e na qualidade de frutos de peras 'Rocha'. O estudo foi conduzido em um pomar comercial localizado no município de São Joaquim-SC, durante as safras de 2014/2015 e 2015/2016. O material consistiu em plantas da cultivar Rocha enxertadas no porta-enxerto de marmeleiro 'BA29'. O AVG foi testado em diferentes doses $\left(60 \mathrm{mg} \mathrm{L}^{-1}\right.$ e $\left.80 \mathrm{mg} \mathrm{L}^{-1}\right)$ e épocas de aplicação [plena floração, uma semana após a plena floração (SAPF) e duas SAPF], tanto isolados quanto combinados. O delineamento experimental foi de casualização por blocos, com pelo menos cinco repetições de uma planta cada. Foram avaliados a frutificação efetiva, o número de frutas por planta, a produção por planta, a produtividade estimada, a massa de fruta, o retorno de floração e a qualidade das frutas. A frutificação efetiva e a produtividade foram consistentemente aumentadas pela aplicação isolada de AVG nas doses de $60 \mathrm{mg} \mathrm{L}^{-1}$ e $80 \mathrm{mg} \mathrm{L}^{-1}$, seja a uma, seja a duas semanas após a plena floração, sem afetar negativamente a qualidade de frutos e o retorno da floração.
\end{abstract}

Termos para indexação: Pyrus communis, reguladores de crescimento de plantas, inibidor de etileno, queda de frutos, qualidade de fruto.

\footnotetext{
'(Paper 088/16). Received July 06,2016. Accepted December 13, 2016.

${ }^{2}$ Agronomist, PhD. Researcher - Temperate Fruit Trees/Crop Science Department. Santa Catarina Agricultural Research and Extension Agency/Experimental Station of São Joaquim, São Joaquim, SC, Brazil. E-mail: mateuspasa@epagri.sc.gov.br; albertobrighenti@ epagri.sc.gov.br.

${ }^{3}$ Agronomist, MSc. PhD Student, Graduate Program, Federal University of Pelotas, Pelotas, RS, Brazil. E-mail: brunocarra@hotmail.com ${ }^{4}$ Biologist, PhD. Biotechnology. São Joaquim, SC, Brazil. E-mail: carpers.rs@gmail.com.

${ }^{5}$ Agronomist, PhD. Researcher - Temperate Fruit Trees/Soil and Plant Nutrition Department. Santa Catarina Agricultural Research and Extension Agency/Experimental Station of São Joaquim, São Joaquim, SC, Brazil. E-mail: marlise@epagri.sc.gov.br.

${ }^{6}$ Agronomist, MSc. Retired Researcher - Temperate Fruit Trees/Crop Science Department. Santa Catarina Agricultural Research and Extension Agency/Experimental Station of São Joaquim, São Joaquim, SC, Brazil. E-mail: pereiraajp@hotmail.com
} 


\section{INTRODUCTION}

Pear production in Brazil was responsible for supplying only $9 \%$ of domestic consumption in 2014 $(\sim 19,000 \mathrm{t})$, of which $57 \%$ were produced in the state of Rio Grande do Sul, $28.5 \%$ in Santa Catarina and, $10 \%$ in Paraná (INSTITUTO BRASILEIRO DE GEOGRAFIA E ESTATÍSTICA, 2014). The other $91 \%(\sim 190,000 \mathrm{t})$ was supplied by imports (FOOD AND AGRICULTURE ORGANIZATION OF THE UNITED NATIONS, 2013). In the state of Santa Catarina, the region of São Joaquim is the most suitable area for pear production, due to its climatic conditions, mainly regarding the accumulation of chilling hours $(\sim 900 \mathrm{~h})$. This scenario results from a series of factors, like the lack of knowledge about the best scion-rootstock combinations, excessive vegetative growth, scarce formation of flower buds (PASA et al., 2011), and low fruit set.

Flowers are pre-programmed to shed after anthesis unless they receive a new stimulus to trigger continued growth, which is commonly given by pollination and fertilization (JACKSON, 2003). However, even when all these conditions are suitable, pear trees frequently fail to produce adequate yields (WEBSTER, 2002). Plant growth regulators are also involved in fruit set of fruit trees (JACKSON, 2003). Several studies have reported positive effects mainly of gibberellins (HAWERROTH et al., 2011; VERCAMMEN; GOMAND, 2008; DECKERS; SCHOOFS, 2002) and thidiazuron (PETRI et al., 2001; BIANCHI et al., 2000) in pear trees when applied at full bloom. However, the higher fruit set induced by these substances is due to a higher rate of parthenocarpy (VERCAMMEN; GOMAND, 2008; PETRI et al., 2001), but often leading to misshapen fruits (BIANCHI et al., 2000), which are not desirable. Besides, the application of gibberellins may reduce flower bud formation and return bloom (DECKERS; SCHOOFS, 2002). Other plant growth regulators, mainly ethylene inhibitors, such as AVG (Aminoethoxyvinilglycine), have shown promising results.

The low fruit set of pears has been partially attributed to ethylene, which is involved on the senescence and abscission of flowers (GREENE, 1980) and young fruits (WEBSTER, 2002). The application of inhibitors of ethylene synthesis, such as AVG, has shown promising results to solve this problem. AVG suppresses ethylene biosynthesis by inhibiting enzymatic activity responsible for the conversion of S-adenosyl methionine to 1-aminocyclopropane-1-carboxylic acid (YANG; HOFFMAN, 1984). Einhorn et al. (2014) observed that ethylene production rate of flowers and fruits of 'Comice' and 'D'Anjou' pears was highest at 14 days after full bloom (DAFB) and was significantly and rate-dependently reduced by AVG. They also observed increased fruit set and yield of both cultivars, but only when AVG was applied two weeks after full bloom (WAFB).

Similar results were observed by Dussi et al. (2002) in 'Packham's Triumph' sprayed with 200 and $400 \mathrm{mg} \mathrm{L}^{-1}$ of AVG applied two WAFB; Sánchez et al. (2011) in 'Abate Fetel' and 'Packham's Triumph' sprayed with $250 \mathrm{mg} \mathrm{L}^{-1}$ of AVG two WAFB; and Einhorn et al. (2013), testing 60 and $80 \mathrm{mg} \mathrm{L}^{-1}$ of AVG in 'D'Anjou' and 'Comice' pears. Based on these information, the application of AVG might be a potential tool to increase fruit set of Brazilian pears orchards.

The objective of this study was, therefore, to evaluate the effect of AVG, sprayed at different rates and timings, on fruit set, yield and fruit quality of 'Rocha' pear, in the region of São Joaquim, SC.

\section{MATERIALS AND METHODS}

The study was performed in a commercial orchard located in the municipality of São Joaquim, in the state of Santa Catarina, Brazil (28 $8^{\circ} 17^{\prime} 39^{\prime \prime} \mathrm{S}$, $49^{\circ} 55^{\prime} 56^{\prime \prime} \mathrm{W}$, at $1,350 \mathrm{~m}$ of altitude), in the growing seasons of 2014/2015 and 2015/2016. The climate of the region is mesothermal humid $(\mathrm{Cfb})$ according to Köppen-Geiger classification, i.e, temperate climate constantly humid, without dry season, and cool summer (BENEZ, 2005). Average accumulation of temperatures below $7.2{ }^{\circ} \mathrm{C}$ is 900 hours. Climatic conditions during the experiment are shown in figure 1. The soil of the experimental field is a Cambissolo Húmico (Inceptisol), according to the Brazilian soil classification system (SANTOS et al., 2013).

Plant material consisted of 'Rocha' pear trees grafted on quince rootstock 'BA29'. Single axis trees were planted in the winter of 2009 and trained in a central leader system. Trees of 'Packham's Triumph' pear were planted every 10 trees of 'Rocha' as pollinator. Soil fertility was previously corrected according to soil analysis. Trees were spaced at $4 \mathrm{~m}$ between rows and $1 \mathrm{~m}$ within the row, totalizing 2,500 trees per hectare.

In the 2014/2015 growing season treatments consisted of different rates and timings of application of AVG: 1) Control; 2) AVG $60 \mathrm{mg} \mathrm{L}^{-1}$ of active ingredient (a.i.) sprayed 1 WAFB; 3) AVG $60 \mathrm{mg}$ $\mathrm{L}^{-1}$ a.i. 2 WAFB; 4) AVG $80 \mathrm{mg} \mathrm{L}^{-1}$ a.i. 1 WAFB and; 5) AVG $80 \mathrm{mg} \mathrm{L}^{-1}$ a.i. 2 WAFB. In the $2015 / 2016$ 
growing season AVG $\left(60 \mathrm{mg} \mathrm{L}^{-1}\right.$ a.i. $)$ was sprayed at different timings: 1) Control; 2) Full bloom (FB); 3) 1 WAFB; 4) 2 WAFB; 5) FB + 1 WAFB and; 6) FB + $1 \mathrm{WAFB}+2 \mathrm{WAFB}$. Full bloom occurred in 09/21/14 and $09 / 15 / 15$ in the $2014 / 15$ and $2015 / 2016$ growing seasons, respectively. The source of AVG was the commercial product Retain ${ }^{\circledR}(15 \%$ a.i. w:w, Valent bioscience Corporation, IL, USA). All solutions were supplemented with $0.05 \%$ (v:v) of nonionic silicone surfactant (Break-Thru, BASF Corp., Research Triangle Park, NC). Trees were sprayed with a motorized hand-gun backpack sprayer (Stihl SR 450, Stihl Ferramentas Motorizadas Ltda, São Leopoldo, RS) with a flow rate of $2.64 \mathrm{~L} \mathrm{~min}^{-1}$. The application water $\mathrm{pH}$ was $\sim 6.95$. Trees were sprayed during the morning, with temperature ranging from 20 to $25^{\circ} \mathrm{C}$, relative humidity of $85-95 \%$ and wind speed not exceeding $7 \mathrm{~km} \mathrm{~h}^{-1}$.

At full bloom, all flower clusters per tree were counted and blocking was performed according to bloom density. Trees were arranged in a randomized complete block design with six (2014/15) and five $(2015 / 16)$ replicates of three trees each. Only the central tree was used for evaluation, leaving one tree at each end as border. At full bloom, all flower clusters per tree were counted and after the last natural fruit drop period occurred ( 40 DAFB) the number of fruit per tree was recorded to calculated fruit set. All flower clusters per tree were counted at full bloom the year following the application to obtain return bloom. Fruit set was obtained from the following formula: number of fruit per tree/number of flower clusters per tree, and expressed as number of fruit per flower cluster. Trees were harvested at commercial maturity, in 02/09/2015 (2014/15) and 02/05/2016 (2015/16). The total number of fruit per tree was counted and weighed $(\mathrm{kg})$. From these data, the following parameters were calculated: yield per tree $(\mathrm{kg})$; average fruit size $(\mathrm{g})$; yield $(\mathrm{t}$ $\mathrm{ha}^{-1}$ ); and yield efficiency ( $\left.\mathrm{kg} \mathrm{cm}^{-2}\right)$, calculated as the reason between production per tree and trunk cross $^{-}$sectional area (TCSA). TCSA was determined according to Pasa et al. (2012), from the trunk diameter measured at $15 \mathrm{~cm}$ above the graft union with a digital caliper, at the beginning of the trial and at the end of each growing season.

At harvest, in the 2015/16 growing season, samples of 15 fruit per replicate (tree) were taken for fruit quality analysis. Fruit firmness was measured in Newton with a digital firmness tester, model 53205 (TR Di Turoni, Forli, Italy), using an $8 \mathrm{~mm}$ diameter probe. Sections of skin, $2 \mathrm{~cm}$ in diameter, were removed at the widest point of the fruit on opposite sides prior to the determination of fruit firmness. After fruit firmness measurements, a composite sample per replicate was juiced, and 0.5 $\mathrm{mL}$ of juice was placed onto a digital refractometer, model PR-32 (Atago Co., Tokyo, Japan) to determine soluble solids content, expressed as ${ }^{\circ}$ Brix. From these samples, fruit diameter (at the widest point) and length were also measured with a digital caliper, expressed in millimeters. Number of viable seeds per fruit was assessed by cutting the fruit in two halves and manually removing and counting the seeds of each fruit individually.

Statistical analyses were performed using the R software (R CORE TEAM, 2014), with the package ExpDes (FERREIRA et al., 2013). Data were analyzed for statistical significance by means of F test. Duncan's test was performed to compare treatments when analysis of variance showed significant differences among means.

\section{RESULTS AND DISCUSSION}

Fruit set was increased by AVG application in both seasons. In the 2014/15 growing season, the fruit set of trees sprayed with AVG $60 \mathrm{mg} \mathrm{L}^{-1}$ and $80 \mathrm{mg} \mathrm{L}^{-1} 1 \mathrm{WAFB}$ was greater than control. In the 2015/16 growing season, AVG $\left(60 \mathrm{mg} \mathrm{L}^{-1}\right)$ increased fruit set when applied at 1 WAFB, 2 WAFB and the combination FB + 1 WAFB + 2 WAFB, compared to control and FB trees (Table 1). Significant differences among treatments for the number of fruit per tree, yield per tree and estimated yield were observed (Table 1). In both seasons, all AVG treatments, but AVG applied at FB, increased number of fruits per tree. Yield per tree and estimated yield, in the 2014/15 growing season, were greater with AVG $80 \mathrm{mg} \mathrm{L}^{-1}$ 1 WAFB, which did not differ of AVG $60 \mathrm{mg} \mathrm{L}^{-1} 1$ WAFB. In the 2015/16 growing season, all timings of AVG application, except FB, resulted in greater yield per tree and estimated yield than control trees (Table 1). Yield efficiency was significantly affected only in 2014/15, where control trees showed the lowest values, not differing only of AVG $60 \mathrm{mg} \mathrm{L}^{-1} 2$ WAFB. Greater yield efficiency in response to AVG was also observed in 'Packham's Triumph' pear trees (DUSSI et al., 2002; SÁNCHEZ et al., 2011).

Similar results to those found in our study were previously reported by Einhorn et al. (2013), where the application of 40 and $80 \mathrm{mg} \mathrm{L}^{-1}$ of AVG, increased fruit set, number of fruit per tree and yield of 'd'Anjou' and 'Comice' when applied 2 WAFB. Sánchez et al. (2011) also reported greater fruit set and yield of 'Abate Fetel' and 'Packham's Triumph' pears in response to AVG $250 \mathrm{mg} \mathrm{L}^{-1}$ sprayed at 2 
WAFB, as well as Dussi et al. (2002) in 'Packham's Triumph'. These results may be attribute do reduction in ethylene synthesis, since this plant hormone is involved in the senescence and abscission of flowers and young fruits (GREENE, 1980), and the rate of ethylene production of flowers and fruits usually peaks at 2 WAFB (Einhorn et al., 2014), which was the moment of greater increase in fruit set in several studies. In our study we also have observed increased fruit set in response to AVG sprayed at 2 WAFB, but the results show that yield and estimated yield were greater when AVG was sprayed at 1 WAFB in the 2014/2015 growing season. Most of the studies have tested AVG applications at either FB or 2 WAFB, but none have studied its effects when sprayed at 1 WAFB. However, our study suggests that we have the first peak of ethylene production around 1 WAFB, but further studies are necessary in order to elucidate the rate of ethylene production in our conditions.

No differences in fruit set among AVG rates at either 1 or 2 WAFB were observed. Then, the lower AVG rate would be recommended by economic reasons. The application of $\mathrm{AVG}$ in multiple timings did not result in additional fruit set as expected, compared to single applications, except when compared to applications at FB, which did not differ of control trees. Indeed, the application of AVG at FB reduced the yield of 'Abate Fetel' and 'Packham's Triumph' pears (SÁNCHEZ et al., 2011). The reason AVG did not affect fruit set when applied at $\mathrm{FB}$, and in some cases even reduced the yield, is probably because ethylene biosynthesis is suggested do trigger the early phase of pollen tube growth (JONES; WOODSON, 1997), so its inhibition at full bloom would not benefit the pollination process, impairing fruit set.

No differences in fruit weight and return bloom were observed among treatments (Table 1). Reduction in fruit weight is usually associated with higher crop load (ROBINSON, 2011) as found by Dussi et al. (2002) in AVG treated 'Packham's Triumph' trees. However, the greater crop load of AVG treated trees did not influence fruit weight in our study, probably because the regular crop load, considering no AVG treatment, was under the maximum crop load capacity of the trees. The absence of negative effects over return bloom is highly desirable, since it would potentially reduce the yield the season following application.

Fruit firmness, soluble solids, fruit length, and fruit length/fruit diameter were not significantly affected by AVG rate or timing (Table 2). Despite inhibiting ethylene biosynthesis (YANG; HOFFMAN, 1984), which is involved in fruit ripening, seems that early applications of AVG do not influence fruit quality attributes, as we have found in the present study. Fruit shape was similarly not affected, overcoming the misshapen fruit problem usually associated with other plant growth regulators used to increase fruit set of pears, such as thidiazuron and gibberellins (BIANCHI et al., 2000).

Significant differences among treatments were found for the number of seeds per fruit. The lower number of seeds per fruit was observed when AVG was applied at FB and FB + 1 WAFB, which did not differ of FB +1 WAFB +2 WAFB (Table 2). Overall, the application of AVG at FB, either alone or in combination with other timings, reduced the number of seeds per fruit. The application of AVG at FB also reduced the number of seeds of 'Comice' and 'd'Anjou' pears (EINHORN et al., 2013). As mentioned before, this is probably a result of early inhibition of ethylene biosynthesis which is suggested do trigger the early phase of pollen tube growth (JONES; WOODSON, 1997). Thus, the reduction in pollen tube growth probably impaired the fertilization process and consequently the number of seeds. However, the reduction in the number of seeds did not result in lower yield or fruit quality. 
TABLE 1- Fruit set, number of fruit per tree, yield per tree, estimated yield, yield efficiency, fruit weight and return bloom of 'Rocha' pears in response to AVG sprayed at different rates and timings (2014/15), and at $60 \mathrm{mg} \mathrm{L}^{-1}$ at different timings (2015/16). São Joaquim, SC.

\begin{tabular}{|c|c|c|c|c|c|c|c|}
\hline Treatment & $\begin{array}{l}\text { Fruit set } \\
\text { (number } \\
\text { of fruit/ } \\
\text { flower } \\
\text { cluster) }\end{array}$ & $\begin{array}{c}\text { Number } \\
\text { of fruit } \\
\text { per tree }\end{array}$ & $\begin{array}{l}\text { Yield } \\
\text { per tree } \\
(\mathrm{kg})\end{array}$ & $\begin{array}{c}\text { Estimated } \\
\text { yield }\left(\mathrm{t} \mathrm{ha}^{-1}\right)\end{array}$ & $\begin{array}{c}\text { Yield } \\
\text { efficiency } \\
\left(\mathrm{kg} \mathrm{cm}^{-2}\right)\end{array}$ & $\begin{array}{c}\text { Fruit } \\
\text { weight (g) }\end{array}$ & $\begin{array}{l}\text { Return } \\
\text { bloom } \\
\text { (number } \\
\text { of flower } \\
\text { clusters) }\end{array}$ \\
\hline & \multicolumn{7}{|c|}{$2014 / 15$} \\
\hline Control & $0.12 \mathrm{~b}$ & $6.8 \mathrm{~b}$ & $1.2 \mathrm{c}$ & $2.9 \mathrm{c}$ & $0.1 \mathrm{c}$ & 168.1 & 67.1 \\
\hline $60 \mathrm{mg} \mathrm{L}^{-1} 1 \mathrm{WAFB}$ & $0.38 \mathrm{a}$ & $18.0 \mathrm{a}$ & $3.0 \mathrm{ab}$ & $7.5 \mathrm{ab}$ & $0.3 \mathrm{ab}$ & 167.4 & 45.7 \\
\hline $80 \mathrm{mg} \mathrm{L}^{-1} 1 \mathrm{WAFB}$ & $0.39 \mathrm{a}$ & $24.0 \mathrm{a}$ & $4.0 \mathrm{a}$ & $10.0 \mathrm{a}$ & $0.4 \mathrm{a}$ & 166.2 & 55.4 \\
\hline $60 \mathrm{mg} \mathrm{L}^{-1} 2 \mathrm{WAFB}$ & $0.22 \mathrm{ab}$ & $15.6 \mathrm{a}$ & $2.4 \mathrm{~b}$ & $6.1 \mathrm{~b}$ & $0.2 \mathrm{bc}$ & 155.6 & 38.8 \\
\hline $80 \mathrm{mg} \mathrm{L}^{-1} 2$ WAFB & $0.24 \mathrm{ab}$ & $18.2 \mathrm{a}$ & $2.8 \mathrm{~b}$ & $7.0 \mathrm{~b}$ & $0.3 \mathrm{ab}$ & 153.3 & 45.3 \\
\hline \multirow[t]{2}{*}{$P>F$} & 0.02 & 0.01 & $<0.01$ & $<0.01$ & $<0.01$ & 0.36 & 0.31 \\
\hline & \multicolumn{7}{|c|}{$2015 / 16$} \\
\hline Control & $0.29 \mathrm{~b}$ & $24.8 \mathrm{~b}$ & $3.9 \mathrm{~b}$ & $9.7 \mathrm{~b}$ & 0.3 & 156.5 & 112.6 \\
\hline FB & $0.38 \mathrm{~b}$ & $28.6 \mathrm{ab}$ & $4.0 \mathrm{~b}$ & $9.9 \mathrm{~b}$ & 0.5 & 141.5 & 98.6 \\
\hline $1 \mathrm{WAFB}$ & $0.59 \mathrm{a}$ & $42.0 \mathrm{a}$ & $6.3 \mathrm{a}$ & $15.7 \mathrm{a}$ & 0.5 & 149.3 & 143.2 \\
\hline 2 WAFB & $0.57 \mathrm{a}$ & $41.5 \mathrm{a}$ & $6.2 \mathrm{a}$ & $15.6 \mathrm{a}$ & 0.5 & 149.7 & 100.2 \\
\hline $\mathrm{FB}+1 \mathrm{WAFB}$ & $0.47 \mathrm{ab}$ & $41.5 \mathrm{a}$ & $6.4 \mathrm{a}$ & $16.1 \mathrm{a}$ & 0.5 & 154.9 & 145.2 \\
\hline $\mathrm{FB}+1 \mathrm{WAFB}+2 \mathrm{WAFB}$ & $0.65 \mathrm{a}$ & $40.2 \mathrm{a}$ & $5.7 \mathrm{a}$ & $14.4 \mathrm{a}$ & 0.5 & 147.4 & 113.0 \\
\hline$P>F$ & $<0.01$ & 0.03 & $<0.01$ & $<0.01$ & 0.7 & 0.25 & 0.20 \\
\hline
\end{tabular}

*Different letters within column indicate significant differences according to Duncan's test $(\mathrm{p}<0.05)$. FB: Full bloom. WAFB: Weeks after full bloom.

TABLE 2- Fruit firmness, soluble solids, fruit length, fruit diameter, fruit length/fruit diameter, and number of seeds per fruit of 'Rocha' pears in response to AVG $\left(60 \mathrm{mg} \mathrm{L}^{-1}\right)$ sprayed at different timings, in the growing season of 2015/16. São Joaquim, SC.

\begin{tabular}{|c|c|c|c|c|c|}
\hline reatmes & $\begin{array}{l}\text { Fruit } \\
\text { firmness } \\
(\mathrm{N})\end{array}$ & $\begin{array}{l}\text { Soluble solids } \\
\left.\text { ( }{ }^{\circ} \text { brix }\right)\end{array}$ & $\begin{array}{l}\text { Fruit } \\
\text { length } \\
(\mathrm{mm})\end{array}$ & $\begin{array}{l}\text { Fruit diameter } \\
\qquad(\mathrm{mm})\end{array}$ & $\begin{array}{l}\text { Fruit length/ } \\
\text { Fruit diameter }\end{array}$ \\
\hline
\end{tabular}

\begin{tabular}{lcccccc}
\hline Control & 51.47 & 12.4 & 84.0 & 68.7 & 1.22 & $2.0 \mathrm{ab}$ \\
FB & 50.37 & 11.6 & 82.9 & 67.1 & 1.25 & $1.3 \mathrm{c}$ \\
1 WAFB & 53.74 & 11.7 & 85.6 & 69.2 & 1.24 & $2.3 \mathrm{a}$ \\
2 WAFB & 55.77 & 12.2 & 84.0 & 69.3 & 1.21 & $1.8 \mathrm{ab}$ \\
FB + 1 WAFB & 57.07 & 11.8 & 84.4 & 68.9 & 1.22 & $1.2 \mathrm{c}$ \\
FB +1 WAFB +2 WAFB & 53.97 & 11.9 & 81.2 & 67.4 & 1.23 & $1.6 \mathrm{bc}$ \\
$P>F$ & 0.14 & 0.06 & 0.08 & 0.09 & 0.64 & 0.01 \\
\hline
\end{tabular}

*Different letters within column indicate significant differences according to Duncan's test $(\mathrm{p}<0.05)$. FB: Full bloom. WAFB: Weeks after full bloom. 


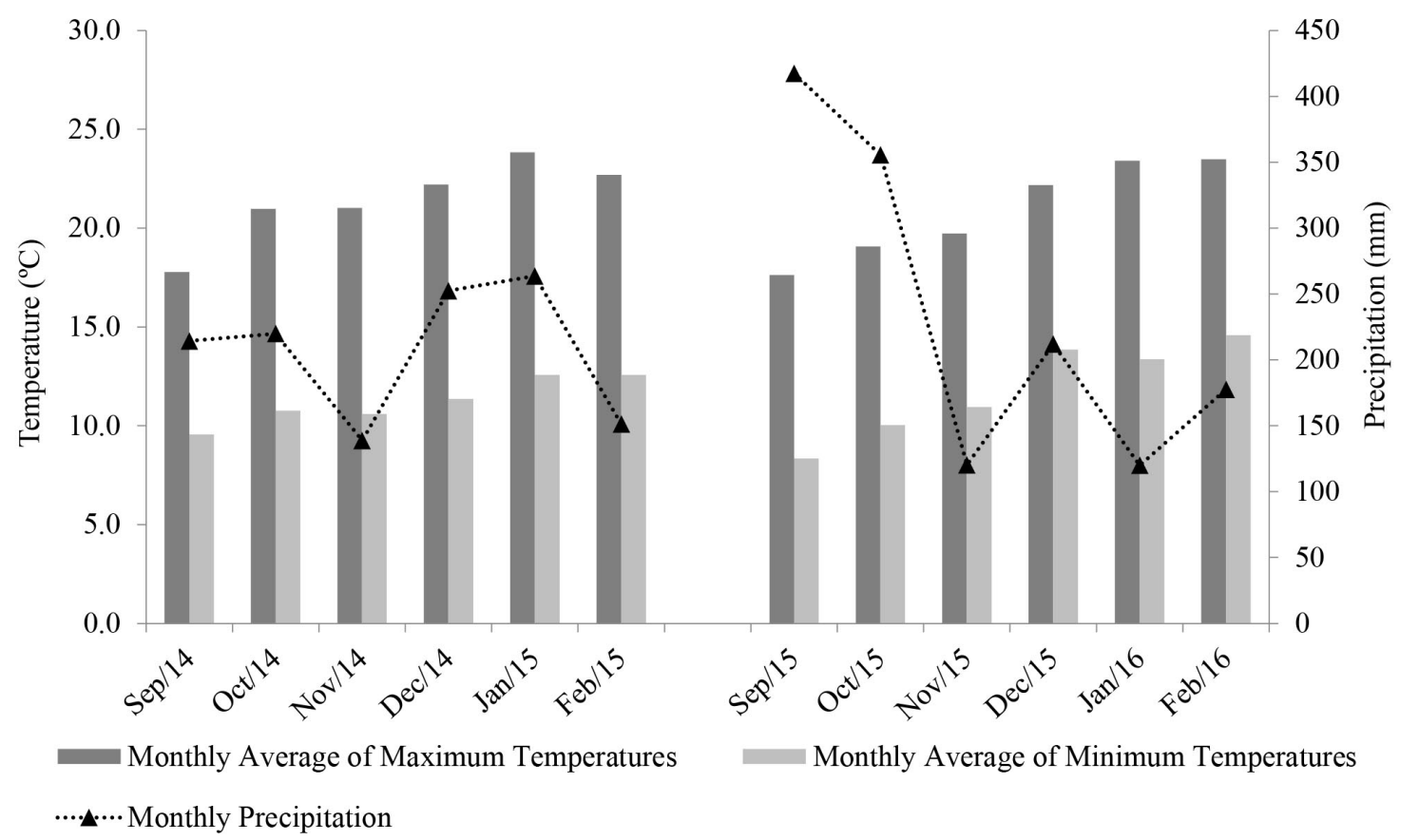

FIGURE 1- Weather conditions of the experimental field located at the municipality of São Joaquim, in the state of Santa Catarina, Brazil. Data obtained from the weather station located at the Experimental Station of São Joaquim/Epagri. São Joaquim, SC. INMET/ BDMEP.

\section{CONCLUSIONS}

Fruit set and yield are increased by single applications of AVG 60 and $80 \mathrm{mg} \mathrm{L}^{-1}$ at either 1 or 2 weeks after full bloom.

Fruit quality attributes and return bloom are not affected by AVG.

The application of AVG at full bloom reduces the number of seeds per fruit.

\section{ACKNOWLEDGEMENTS}

To the National Council for Scientific and Technological Development (CNPq) for grant support (Process: 443135/2014-2).

\section{REFERENCES}

BENEZ, M.C. Dados e informações biofísicas da Unidade de Planejamento Regional Planalto Sul Catarinense - UPR 3. In: DUFLOTH, J.H.; CORTINA, N.; VEIGA, M.; MIOR, L.C. (Ed.). Estudos básicos regionais de Santa Catarina. Florianópolis: EPAGRI, 2005. CD-ROM

BIANCHI, V.J.; SILVEIRA, C.A.; FARIA, J.L.; FACHINELLO, J.C.; SILVA, J.B. Aumento da frutificação efetiva de pereiras cultivar Garber com uso de $\mathrm{AG}_{3}$ e TDZ. Revista Brasileira de Agrociência, Pelotas, v.6, p.191-193, 2000.

DECKERS, T.; SCHOOFS, H. improvement of fruit set on young pear trees cultivar Conference with gibberellins. Acta Horticulturae, The Hague, v.596, p.735-743, 2002.

DUSSI, M.C.; SOSA, D.; CALVO, G. effects of retain ${ }^{\mathrm{TM}}$ on fruit maturity and fruit set of pear cultivars Williams and Packham's Triumph. Acta Horticulturae, The Hague, v.596, p.767-771, 2002. 
EINHORN, T.; ARRINGTON, M.; WANG, Y.; FERNANDES, A. P.; PASA, M. S. Evaluation of ABA and AVG to manage fruit set and crop load of 'd'Anjou', 'Bartlett' and 'Comice' pear. In: INTERNATIONAL PEAR SYMPOSIUM, Leuven. Program and Abstracts... Bélgica: ISHS, 2014.

EINHORN, T.C.; PASA, M.S.; TURNER, J. Promotion and management of pear fruiting. Good Fruit Grower, Yakima, v.64, p.42-43, 2013.

FERREIRA, E.B.; CAVALCANTI,P.P.; NOGUEIRA, D.A. ExpDes: experimental designs package. R Package Version 1.1.2, 2013. Disponível em: $\underline{\mathrm{http}: / /}$ cran.r-project.org/web/packages/ExpDes/index. html >. Acesso em: 26 nov. 2013.

FOOD AND AGRICULTURE ORGANIZATION OF THE UNITED NATIONS. FAOSTAT: TradE crops and livestock products. Disponível em: $<\mathrm{http} / / /$ faostat3.fao.org/download/T/TP/E > . Acesso em: 6 mar. 2016.

GREENE, D.W. Effect of silver nitrate, aminoethoxyvinylglycine and gibberellins A $4+7$ plus 6-benzylaminopurine on fruit set and development of 'Delicious' apples. Journal of the American Society for Horticultural Science, Alexandria, v.105, p.717-720, 1980.

HAWERROTH, F.J.; HERTER, F.G.; FACHINELLO, J.C.; PETRI, J.L.; PREZOTTO, M.E.; HASS, L.B.; PRETTO, A. Aumento da produção de pereira asiática pelo uso de fitorreguladores. Ciência Rural, Santa Maria, v.41, p.1750-1754, 2011.

INMET - Instituto Nacional de Meteorologia. Banco de Dados Meteorológicos para Ensino e Pesquisa. Ministério da Agricultura, Pecuária e Abastecimentyo, 2016. Disponível em: $\leq$ http://www. inmet.gov.br/portal/index.php?r=bdmep/bdmep $>$. Acesso em: 3 jun. 2016.

INSTITUTO BRASILEIRO DE GEOGRAFIA E ESTATÍSTICA. Censo agropecuário 2014: lavoura permanente. Disponível em: $<$ http://www.ibge.gov. br/estadosat/ $>$. Acesso em: 13 mar. 2016.

JACKSON, J.E. Biology of apples and pears. Cambridge: Cambridge University Press, 2003. 488p.
JONES, M.L.; WOODSON, W.R. Pollinationinduced ethylene in carnation: Role of stylar ethylene in corolla senescence. Plant Physiology, Washington, v.115, p.205-212, 1997.

PASA, M.S.; FACHINELLO, J.C.; SCHMITZ, J.D.; SOUZA, A.L.K.; HERTER, F.G. Hábito de frutificação e produção de pereiras sobre diferentes porta-enxertos. Pesquisa Agropecuária Brasileira, Brasília, DF, v.46, p.998-1005, 2011.

PASA, M.S.; FACHINELLO, J.C.; SCHMITZ, J.D.; SOUZA, A.L.K; DE FRANCESCHI, E. Desenvolvimento, produtividade e qualidade de peras sobre porta-enxertos de marmeleiro e Pyrus calleryana. Revista Brasileira de Fruticultura, Jaboticabal, v.34, n.3, p.873-880, 2012.

PETRI, J. L.; SCHUCK, E.; LEITE, G.B. Efeito do thidiazuron (TDZ) na frutificação de fruteiras de clima temperado. Revista Brasileira de Fruticultura, Jaboticabal, v.23, n.3, p.513-517, 2001.

R CORE TEAM. R: A language and environment for statistical computing. Vienna: R Foundation for Statistical Computing, 2014. Disponível em: $<$ http:// www.R-project.org/>.

ROBINSON, T.L. High density pear production with Pyrus communis rootstocks. Acta Horticulturae, The Hague, v.909, p.259-270, 2011.

SÁNCHEZ, E.; CURETTI, M.; RETAMALES, J. Effect of AVG application on fruit set, yield and fruit size in 'Abate Fetel' and 'Packam's Triumph' pears in a semi-commercial statistical trial. Acta Horticulturae, The Hague, v.909, p.435-440, 2011.

SANTOS, H.G.; JACOMINE, P.K.T.; ANJOS, L.H.C.; OLIVEIRA, V.A.; LUMBRERAS, J.F.; COELHO, M.R.; ALMEIDA, J.A.; CUNHA, T.J.F.; OLIVEIRA, J.B. Sistema brasileiro de classificação de solos. 3.ed. rev. e ampl. Brasília, DF: Embrapa, 2013.

VERCAMMEN, J; GOMAND, A. Fruit set of 'Conference': a small dose of gibberellins or Regalis. Acta Horticulturae, The Hague, v.800, n.1, p.131138, 2008. 
WEBSTER, A.D. Factors influencing the flowering, fruit set and fruit growth of European pears. Acta Horticulturae, The Hague, v.596, p.699-709, 2002.
YANG, S.F.; HOFFMAN, N.E. Ethylene biosynthesis and its regulation in higher plants. Annual Review of Plant Physiology, Palo Alto, v.35, p.155-189, 1984. 